International Journal of Library and Information Science Studies

Vol.8, No.1, pp.33-38, 2022

Print ISSN: 2059-9056 (Print)

Online ISSN: 2059-9064(Online)

\title{
PERCEIVED CONSTRAINTS TO THE UTILIZATION OF ICT FACILITIES IN SELECTED UNIVERSITY LIBRARIES IN IMO STATE, NIGERIA
}

\author{
Ijeoma Irene Bernard., Doris Chinyere Obiano and Chioma Esther Osuji \\ Research, Training and Statistics Unit, University Library, Federal University of Technology, \\ Owerri, Imo State, Nigeria
}

Citation: Ijeoma Irene Bernard., Doris Chinyere Obiano and Chioma Esther Osuji (2022) Perceived Constraints to the Utilization of ICT Facilities in Selected University Libraries in Imo State, Nigeria, International Journal of Library and Information Science Studies, Vol.8, No.1, pp.33-38

\begin{abstract}
The purpose of this study was to ascertain the challenges of utilization of Information and Communication Technology (ICT) facilities in two selected University Libraries in Imo State. A sample size of sixty (60) library staff from the two selected University Libraries was used. Data were analyzed using mean and standard deviation. The results showed that the major constraints faced in use of ICT tools include epileptic power supply, lack of access to ICT facilities and lack of adequate office/accomodation. From the above findings, the study recommended that the institutions should go ahead to acquire more current and relevant ICT facilities that are not yet available. That the staff should be given free access to the facilities and provide adequate office space for operations. There should be regular training of staff on ICT both in-house and otherwise so that staff will be more equipped to use the facilities for enhancement.
\end{abstract}

KEYWORDS: library, ICT, universities, facilities, staff

\section{INTRODUCTION}

It is an indisputable fact that the introduction of information and communication technology (ICT) into academic libraries in the 21 st century has tremendously brought some drastic changes in the service delivery functions of libraries. According to Husain and Nazim (2015), the vital activities of libraries comprise collection development, reference services management, document delivery service, access to organised collections held by the library and assist users in information search and retrieval. There is also no doubt that, in a relatively short period, Information Communication Technology has increasingly become very important in our daily lives and also in our Nigerian educational system. This has given birth to the virtual library where users can access a myriad of information by a click of a computer button regardless of their geographical location (Olise, 2010).

Ifinedo (2006) buttressed this by indicating that, globally, university libraries are now moving from the traditional method of providing information which facilitates learning and research as well as attaining access to varieties of information without wasting the precious time of users. Additionally, the acceptance and use of ICT in the academic library will not only contribute to the

@ECRTD-UK https://www.eajournals.org Journal Level DOI: https://doi.org/10.37745/ijliss.15 
achievement of the library's mission and goals but to the realisation of the aims and vision of the entire university and the nation as a whole. ICT in all sectors of education as a learning instrument has improved students-centered and self-directed learning since ICT expedites the acquisition of knowledge (Fu, 2013). Additionally, it has been discovered that tremendous development has been seen in the field of Library and Information Science due to the faster growth in technology. Subsequently, due to the use of internet and technology, the library work has become very fast and thereby enabling the needs of library users to be met with speed and accuracy. Hence, this study has been carried out to explore the challenges of use of ICT facilities in two universities

\section{Problem statement}

Emerging ICTs have changed traditional libraries into knowledge centres and librarians' function more like consulting information engineers or knowledge managers (Sampath, Kumar \& Biradar, 2010). So also, one of the most prominent advantages of ICT is to provide ICT-based information services to meet the users' demands (Woodward, 2009). The modern technology has carried momentous changes in different aspects of library management. From housekeeping operation to user's management, and have been largely achieved through the applications of internet and library software (Woodward, 2009).

Omekwu (2006) has indicated that although many professionals are aware of the vital role that IT and the internet could play in cultural documentation, dissemination and destabilization, they do not possess the appropriate skills to assist users in exploiting web-based information. He stressed that librarians have not moved with the times. They have not repositioned themselves to make a significant difference in the digital age" Omekwu (2006).

Adeyoyin (2006) acknowledges that technology is becoming pervasive, but laments that "there was a need for knowledge acquisition among librarians to be able to offer efficient services in the emerging ICT era and that the ICT literacy among the librarians was low and hands-on practical experience was lacking among the librarians in some cases". He also indicated that though, there has been a tremendous explosion in the information and communication technology industry, majority of West African university librarians both from Anglophone and Francophone countries surveyed, are yet to come to terms with reality." And this has negatively impacted the application of ICT in the services of libraries (Adeyoyin, 2006).

A similar study by Amekuedee (2005) discovered that nearly 50\% of librarians he sampled for his study were not adequately trained in using ICT in their respective jobs and recommended continuous training in ICT for librarians on the job. In addition, a study by Omona and IkojaOdongo (2006) also confirmed that lack of ICT skills was a major problem facing librarians and library users.

Preliminary investigations made by the researchers revealed that, management of the two Universities have invested heavily in acquiring ICT facilities for their Libraries with the purpose of enhancing teaching, learning and research. However, the use of these ICT facilities by students

@ECRTD-UK https://www.eajournals.org Journal Level DOI: https://doi.org/10.37745/ijliss.15 
is not encouraging. It was for this reason that this paper sought to explore the challenges that users (librarians) face as they use ICT facilities in search of resources in the library. The specific objectives therefore include to:

1 ascertain perceived constraints to the utilization of ICT facilities by library staff of the University Libraries in Imo State.

2. identify perceived solutions to non-utilization of (ICT) facilities by Library staff in the university Libraries in Imo State.

\section{METHODOLOGY}

Imo lies in the South East of Nigeria with Owerri as its capital and largest city. Located in the south-eastern region of Nigeria, it occupies the area between the lower River Niger and the upper and middle Imo River. Imo State is bordered by Abia State on the East, River Niger and Delta State to the West, Anambra State on the North and Rivers State to the South.[IMSG, 2010.] The State lies within latitudes $4^{\circ} 45^{\prime} \mathrm{N}$ and $7^{\circ} 15^{\prime} \mathrm{N}$, and longitude $6^{\circ} 50^{\prime} \mathrm{E}$ and $7^{\circ} 25^{\prime} \mathrm{E}$ with an area of around 5,100 sq km.[IMSG,2010.] The state is over 6.8 million people in year 2021 and the population density varies from $230-1,400$ people per square kilometre. Christianity is the predominant religion. In addition to English being official language, Imo state is a predominantly Igbo speaking state, with Igbo people constituting a majority of 98\% (IMSG,2010). There are several institutions of higher learning including state and federal government run institutions. They are as follows: Imo State University; Federal University of Technology, Owerri; Federal Polytechnic, Nekede; Eastern Palm University, Orlu; Imo State Polytechnic, Umuagwo; Alvan Ikoku College of Education; Technological Skills Acqisition Institute, Orlu. However, Federal University of Technology and Imo State University, Owerri have been selected for the study.

The Federal University of Technology Owerri (FUTO) is a federal government university in Owerri West, the capital of Imo State, Nigeria. The university is bounded by the communities of Eziobodo, Umuchima, Ihiagwa and Obinze. It is the premier federal university of technology in the South-East and South-South parts of Nigeria. The university is the oldest university of technology in Nigeria and was established in 1980 by executive fiat with the composition and appointment of the first provisional council by Nigeria's first Executive President, Shehu Shagari. It became the first of three such universities set up by the Federal Government of Nigeria which sought to establish a University of Technology in each geo-political region and particularly in a state which did not have a conventional university.

The Imo State University (IMSU) was established in 1981 through law No. 4 passed by the Imo State House of Assembly. Established with the vision of pursuing the advancement of learning and academic excellence, the university has been unrelenting in the pursuit of its mission of becoming a citadel of learning, a community with the trademark of excellence in teaching, research and service to humanity, a catalyst as well as an agent for development.

@ECRTD-UK https://www.eajournals.org Journal Level DOI: https://doi.org/10.37745/ijliss.15 
A simple random sampling was adopted. This is because there was a great margin in the number of Library staff in Federal University of Technology Owerri, 124 library staff as at the time of the study, while IMSU has 40 library staff. A random sampling of thirty staff from each University Library was selected making a grand total of 60 library staff.. This was achieved by tagging a number to each name in the list of staff from the different universities and making a random picking of 30 numbers. The names that tallied with the numbers were selected for administration of questionnaire. Questionnaire was used as an instrument for data collection. All the objectives were analyzed on a four (4) point Likert type scale of Strongly Agreed, Agreed, Disagreed and Strongly Disagreed, assigned values of 4 to 1 respectively was used to achieve all the objectives, which is mathematically represented as

$$
\frac{4+3+2+1}{4}=\frac{10}{4}=2.50
$$

Therefore, a mean of 2.50 was adjudged okay and acceptable while any value below 2.50 was not accepted.

\section{RESULTS AND DISCUSSION}

\section{Constraints to the utilization of ICT facilities by the library staff of the universities}

Analysis on the constraints to the utilization of ICT facilities by the Library staff of the universities under study shows that limited access to the facilities has mean(x) score of 3.30 which means that staff are limited to access the facilities of the ICT in the university libraries under study. It is shown that epileptic power supply has become a nagging issue in use of ICT facilities in the libraries with mean $(x)$ score of 3.67, space/inadequate accommodation with mean(x) score of 3.7 and apathy to the acquisition of ICT facilities (x) score 3.92 respectively were all challenges to the use of ICT tools in the sampled libraries.

Haneefa (2007) did a study on the application of Information and Communication Technologies (ICTs) in special libraries in Kerala, India and the findings revealed a lack of adequate ICT infrastructure as the critical factor for users' dissatisfaction. This means that lack of adequate ICT infrastructure and qualified personnel in the application of software, operating systems, network administration and technicians to service and repair computer facilities could hinder the use of ICT facilities in the library's environment. Additionally, it must be noted that for ICT application to thrive in the library environment, there must be an expert to train users on how to use these systems. Unfortunately, the library under investigation does not only lack ICT adequate infrastructure, but it also lacked the necessary human skills and knowledge to incorporate ICT into the library's environment. With respect to the insufficient funding for libraries, this discovery was in support of Ani (2007) who identified that the common challenges that hamper ICT development and its usage involved issues of inadequate infrastructure, financial challenges and poor attitude of policymakers on the issues of ICT and information services

@ECRTD-UK https://www.eajournals.org Journal Level DOI: https://doi.org/10.37745/ijliss.15 
Vol.8, No.1, pp.33-38, 2022

Print ISSN: 2059-9056 (Print)

Online ISSN: 2059-9064(Online)

Table 1: Constraints to the Use of ICT facilities by library staff of the universities.

\begin{tabular}{|l|l|l|l|l|l|l|l|}
\hline Respondents & SA & A & D & SD & X & Decision \\
\hline & Limited access to the facilities & 27 & 18 & 5 & 3 & 3.30 & Positive \\
\hline Epileptic electricity supply & 40 & 10 & 2 & 1 & 3.67 & Positive \\
\hline Space/inadequate accommodation & 39 & 9 & 5 & 4 & 3.71 & Positive \\
\hline Apathy to acquisition of ICT & 33 & 7 & 7 & 6 & 3.92 & Positive \\
\hline
\end{tabular}

Solutions to ICT Use Constraints by library staff of the universities in Imo State

Analysis on the solution to the unavailability and non-utilization of ICT facilities by Library staff of the universities under study shows that training of staff has mean(x) score of 3.92 which means that library staff should be adequately trained to face the future challenges of the global world. It is shown that open access to ICT facilities should be provided and it has the, mean(x) score of 3.62. Provision of regular electricity supply has mean(x) score of 3.88 and the data analyzed from the respondents shows that regular electricity supply should be encouraged. The analysis also shows that provision of adequate accommodation has mean(x) score of 3.37 respectively. This means that all the items analyzed in the table are the solutions to the unavailability and nonutilization of ICT facilities by Library staff of the universities under study.

Table 2 : Solution to ICT Use Constraints by Library Staff of the universities under study.

\begin{tabular}{|l|l|l|l|l|l|l|l|}
\hline & Respondents & SA & A & D & SD & X & Decision \\
\hline & Training of staff & 50 & 2 & 1 & 0 & 3.92 & Positive \\
\hline & Open access to facilities & 41 & 7 & 2 & 3 & 3.62 & Positive \\
\hline & Provision of regular electricity supply & 48 & 4 & 1 & 0 & 3.88 & Positive \\
\hline & Provision of adequate office accommodation & 32 & 12 & 6 & 3 & 3.37 & Positive \\
\hline
\end{tabular}

\section{CONCLUSION}

It was shown that the constraints to ICT facilities usage by library staff are unreliable power supply, inadequate provision of needed hardware and software. Solutions to unavailability and non-utilisation of ICT facilities were proffered. Among these are ; train as many staff as possible on the operation of new system. Equally important is system maintenance to ensure its sustainability, effective implementation involving knowledge of recent technological trends, an analysis library specification and requirements a delineation of library goals and objectives, clearly written policies and procedure management, commitment and support and on-going user education.

\section{References}

Amekuedee, J.O. (2005). An evaluation of library automation in some Ghanaian University Libraries", The Electronic Library, 23(4), pp.442-452.

Ani, O. E. (2007). Information and Communication Technology Adeyoyin, S.O. (2006). ICTLiteracy among the Staff of West Africa University Libraries. The Electronic Library 24 (5), pp. 694-705.

@ECRTD-UK https://www.eajournals.org Journal Level DOI: https://doi.org/10.37745/ijliss.15 
International Journal of Library and Information Science Studies

Vol.8, No.1, pp.33-38, 2022

Print ISSN: 2059-9056 (Print)

Online ISSN: 2059-9064(Online)

Fu, J.S. (2013). ICT in Education: A critical literature Review and its Implications International journal of education and development using information and communication technology, 9 (1), pp. 112- 125. Retrieved: December 21, 2018 from http://ijedict.de c.uwi.edu/viewis sue.php?id =34\#Literature_Reviews.

Haneefa, M. (2007). Application of information and communication technologies in special libraries in Kerala (India). Library Review, 56(7), pp.603-620 from https:// doi.org/10 $.1108 / 00242530710775999$

Husain, S., \& Nazim, M. (2015). Use of different information and communication technologies in Indian academic libraries. Library Review, 64(1/2), 135-153. https://doi.org/10.1108/LR06-2014-0070

Ifinedo, P. (2006). Acceptance and Continuance Intention of Web-Based Learning.

Technologies (WLT) among University Students in a Baltic Country. The Journal of Information Systems in Developing Countries, 23(6), pp. 1-20.IMSG (2010) Exam ethics Commission. Ministry of Education, Owerri

Olise, F.P. (2010). Information and communication technologies (ICTs) and sustainable

Development in Africa: Mainstreaming the millennium development goals (MDGS) into Nigerian's development agenda. Journal of Social Science, 24(3), pp.155-167.

Omekwu, O. C. (2006). Managing information and technology: critical roles for librarians in developing countries. The Electronic Library, 24(6), pp.847-863.

Omona, W., Ikoja-Odongo, R. (2006). Application of Information and Communicatio Technology (ICT) in Health Information Access and Dissemination in Uganda. Journal of Librarianship and Information Science, 38 (1), pp. 45-55.

Sampath Kumar, B.T., \& Biradar, B.S. (2010). Use of ICT in college libraries in Karnataka, India: a survey. Program, 44(3), 271-282. Retrieved December 2, 2018, from https:// doi.org /10.1108/00330 331011064267

Woodward, J. (2009). Creating the Customer-Driven Academic Library. Chicago: Amer Library Assn Editions.

@ECRTD-UK https://www.eajournals.org

Journal Level DOI: https://doi.org/10.37745/ijliss.15 